\title{
Use of silicon photovoltaic cells to provide a second channel in flame emission photometry
}

\author{
R. J. HURST AND A. M. BOLD
}

From the Department of Chemical Pathology, St. Thomas' Hospital Medical School, London

SYNOPSIS Sodium and potassium may be measured simultaneously, using a modified Eppendorf flame photometer. After automatic sampling and dilution of the plasma, the potassium content is measured, using the existing Eppendorf optical and photomultiplier system. The sodium emission is measured by three silicon photovoltaic cells mounted behind an interference filter for sodium, sited on the atomiser casing. The outputs from the photomultiplier and from the silicon cells are recorded by two sensitive recorders. Sixty samples an hour may be estimated, using only $0.12 \mathrm{ml}$. plasma. Reproducibility tests showed a coefficient of variation of $0.4 \%$.

In a previous paper (Bold, Hurst, and McSwiney, 1965) we described the mechanization of an Eppendorf flame photometer for the estimation of sodium, potassium, or calcium in plasma. Sodium in the flame emits light of sufficient intensity to produce a recordable current from three silicon cells mounted on the atomiser casing. This system provides an inexpensive second channel to permit simultaneous estimation of sodium and potassium in plasma.

\section{APPARATUS}

An Eppendorf flame photometer, with sampler and proportioning pump modules, as previously described, is used. Three silicon cells (S $1020 \mathrm{E} \mathrm{11})^{1}$ are wired in parallel, and laid on a paxolin sheet. Holes, just smaller than the silicon cells and sited appropriately, are cut in a second paxolin sheet, which is placed on the first sheet to retain the cells in position. This double sheet is placed in a metal cylinder (of internal diameter $5 \mathrm{~cm}$., and $5 \mathrm{~cm}$. long) and secured with a retaining ring, behind a sodium interference filter ${ }^{2}$ (sodium emission line $589 \mathrm{~m} \mu$ ). The cylinder is mounted on the front of the atomiser casing, at right angles to the port for the normal filter (Fig. 1). The silicon cells are $7 \mathrm{~cm}$. from the burner port. The output from the silicon cells is adjusted by a potentiometer (50K) and fed into a Honeywell Elektronik recorder (Fig. 2), using the 0-1 $\mathrm{mV}$ range.

METHOD

The flame photometer is turned on in the usual way, using a propane:air flame. The potassium filter of the Received for publication 4 July 1966.

${ }^{1}$ Made by the International Rectifier Corporation, El Segundo, California, U.S.A.

'Barr \& Stroud.

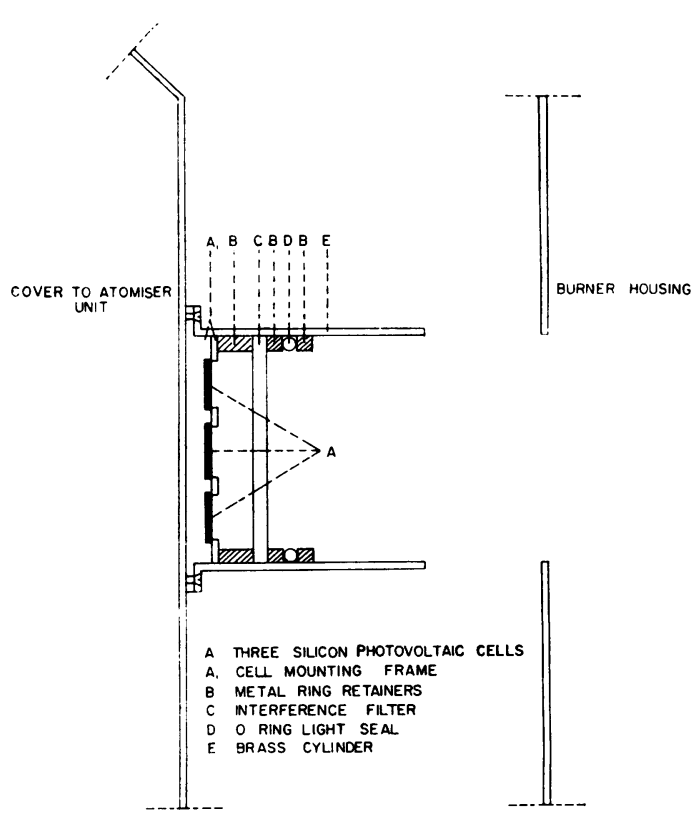

FIG. 1. Diagram of the mounting of the silicon cells.

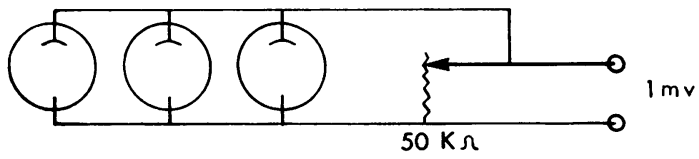

FIG. 2. Diagram of the silicon cell circuit. 
flame photometer is selected. A solution, containing sodium, $160 \mathrm{mEq} . / 1$, and potassium, $7.5 \mathrm{mEq} . / 1$, is sampled continuously for a warming-up period of at least 30 minutes. The potentiometer in the silicon cell circuit and the flame photometer sensitivity control are adjusted to give a deflection of $80 \%$ to $90 \%$ on the recorders measuring sodium and potassium respectively. Standard solutions, containing sodium 100 to $160 \mathrm{mEq} . / \mathrm{l}$. and potassium 2.5 to $7.5 \mathrm{mEq}$./1., are then sampled. These are followed by batches of plasma and reference plasmas to check stability, as previously described.

\section{EXPERIMENTAL}

One silicon cell was found to produce too little output for satisfactory estimation of sodium. When three silicon cells are used, however, a solution containing sodium $160 \mathrm{mEq} . / \mathrm{l}$., diluted $1: 50$ and sprayed into the flame, produced $80 \%$ to $90 \%$ of full-scale deflection on the Honeywell Brown Elektronik recorder, using the 0-1 mV range.

Figure 3 shows the record of an experiment to test the stability and reproducibility of the output of the silicon cells. A solution containing sodium $140 \mathrm{mEq}$./l. was sampled continuously for 15 minutes. An extended standard curve ( 20 to $160 \mathrm{mEq}$./l.) was then run, followed by one specimen of plasma 25 times, each batch of five being followed by a reference plasma. The estimation of this plasma showed a coefficient of variation of $0.4 \%$.
Figure 4 shows the extent to which one sample can contaminate the next sample by 'carry over'. Duplicate samples with high and low sodium concentration were estimated. Under the extreme conditions where a sample with a sodium concentration of $160 \mathrm{mEq}$. 1 . is followed by a sample with a sodium concentration of $100 \mathrm{mEq}$./l., the error is less than $2 \mathrm{mEq} . / 1$.

\section{DISCUSSION}

A silicon cell is a type of photovoltaic cell. It consists essentially of a thin slice of purified silicon crystal. The photovoltaic junction is created by exposing the crystal to boron trichloride at a high temperature, when elemental boron diffuses into the outer layer of the crystal. By nickel plating and tinning, a thin strip is formed on this outer layer, to form the positive terminal. The inner layer of the silicon crystal is exposed and coated to function as the negative terminal. Details of the construction and performance of silicon photovoltaic cells are given by Sasuga (1960).

Compared with selenium cells, silicon cells have reversed polarity; the range of spectral response is also different, that of a silicon cell beginning in the near infra-red and stopping short of the ultra-violet region. Silicon cells tolerate an ambient temperature

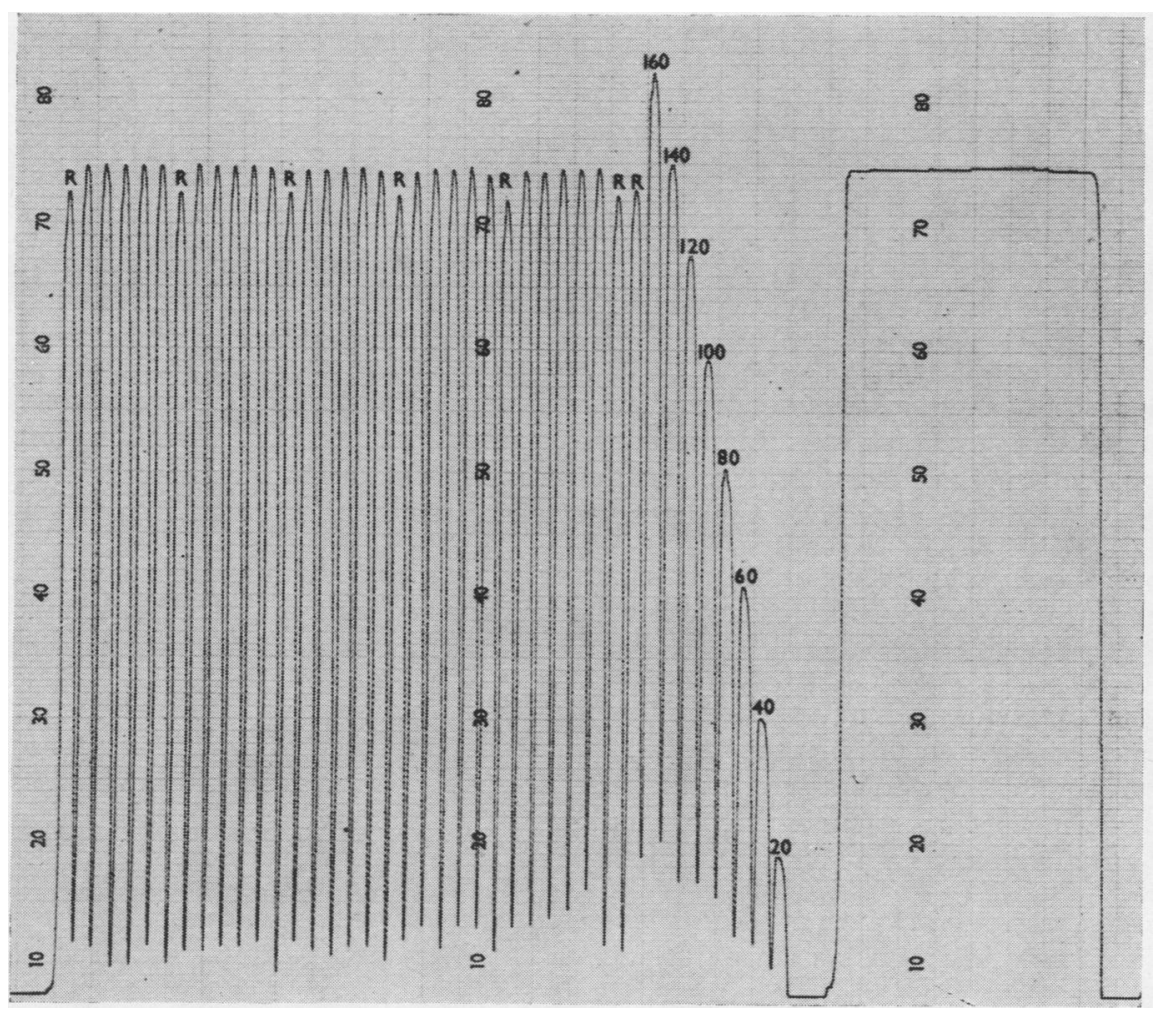

FIG. 3. Photograph of record of sodium estimations by the silicon cells. The record reads from right to left: a solution with a sodium concentration of $140 \mathrm{mEq} . / \mathrm{l}$. was sampled continuously for fifteen minutes. This was followed by an extended standard curve, 20 to 160 being the sodium concentration in mEq./l. There follows the record of one plasma estimated twenty-five times in batches of five, separated by reference plasmas (R). 


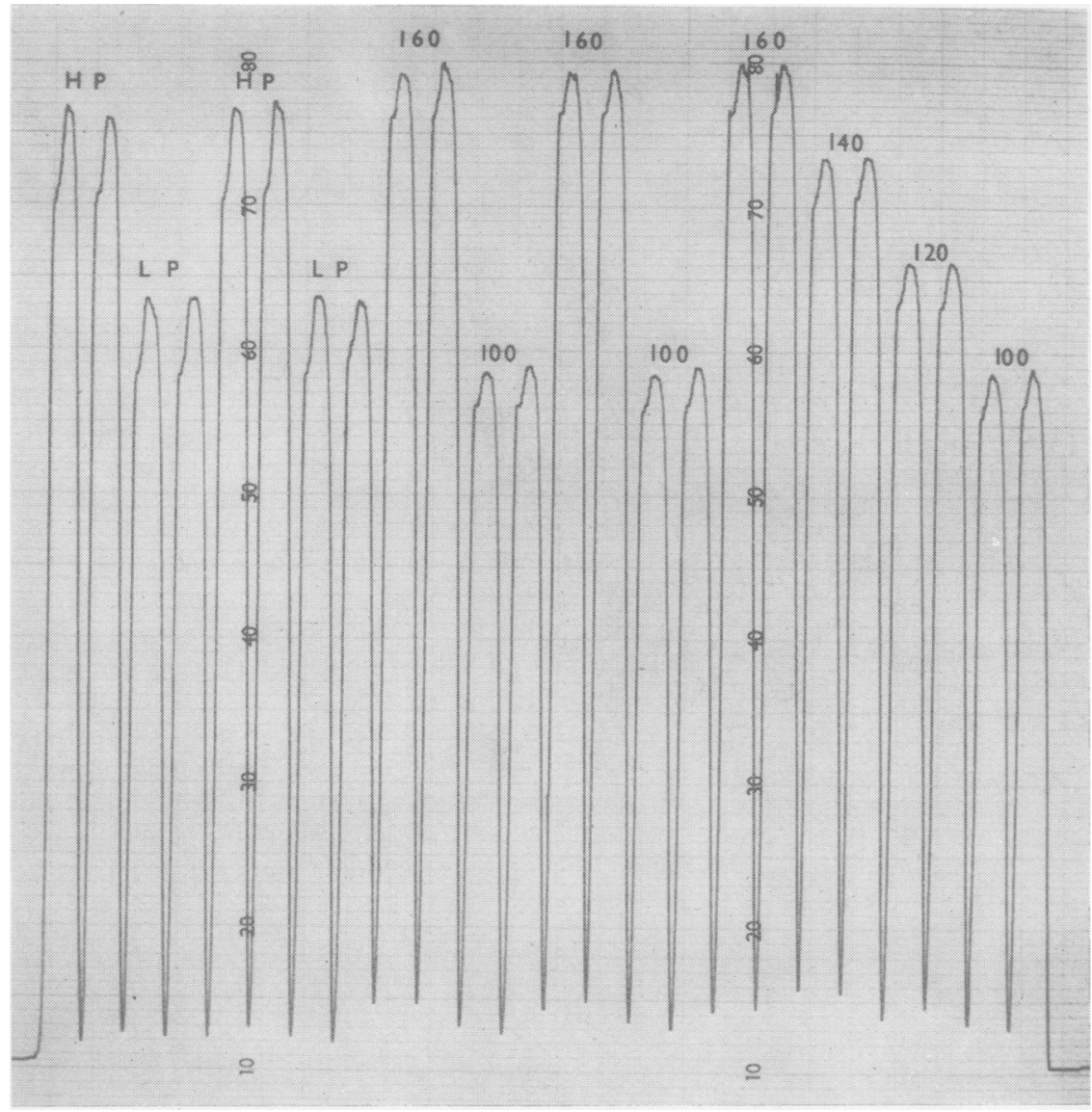

IIG. 4. Photograph of record of sodium estimations by the silicon cells, to show the extent of "carry over'. The record reads from right to left: a duplicate standard curve with sodium concentration 100 to $160 \mathrm{mEq}$./l. is followed by dvplicate aqueous standards containing 160 and $100 \mathrm{mEq}$. sodium/l. and duplicate estimations of plasmas containing a high (HP) or low (LP) sodium concentration.

up to $170^{\circ} \mathrm{C}$., compared with the upper operational temperature of $85^{\circ} \mathrm{C}$. for selenium cells (Sasuga, 1960). Under our conditions, silicon cells have two main advantages: their output for a given illumination from the flame is more stable, and the response to changes in illumination is more rapid.

The output of silicon cells varies with temperature, but is satisfactorily constant when they are warmed up. The output of the silicon cells is at least as stable as that of the photomultiplier in the Eppendorf flame photometer. The system described here is simple to instal and is cheaper than the conventional photomultiplier.

The shape of the standard curve (Fig. 2), although not linear, permits the measurement of differences in sodium concentration of $1 \mathrm{mEq}$./1. We do not yet know the full life of the silicon cells. They have so far been used for two or three hours every week day for over a year, and are still functioning satisfactorily, with only a slight loss of output.

We are now using this system routinely, and no? major snags have come to light. However, if $\frac{}{3}$ accuracy is to be maintained, we must again stress the need for plasma to be free from any fibrin, and for scrupulous attention to the cleanliness of the flame photometer atomiser.

We wish again to thank Miss Joan Dewe who drew the figures and the members of the Photographic Department $N$ of St. Thomas' Hospital Medical School who took the photographs.

\section{REFERENCES}

Bold, A. M., Hurst, R. J., and McSwiney, R. R. (1965). J. clin. Path., $18,240$.

Sasuga, J. (1960). Solar Cell and Photo Cell Handbook. International Rectifier Corporation, El Segundo, California. 